\title{
Stimulasi Perkembangan Anak Dengan Memanfaatkan Barang Bekas di Era New Normal
}

\section{Yuniatari}

UIN Sunan Kalijaga, Yogyakarta, Indonesia yuniatarinew@gmail.com

\section{Suyadi}

UIN Sunan Kalijaga, Yogyakarta, Indonesia suyadi@uin-suka.ac.id

Abstract: Stimulation of Children Development by Using Used Goods in The New Normal Era. The purpose of this study is to describe the application of the watch puzzle game made from used goods that can stimulate children development in the new normal era. This research is a descriptive qualitative type with data collection techniques interviews, observation, and documentation. Researchers conducted participant observations on residents who live in Graha Kencana Housing Blok RR no. 12 with research subjects there are 3 children aged 5-6 years and 2 parents who accompany the children to play. This research was conducted during the Covid-19 pandemic, especially in the new normal era. The results showed that the educational game of watch puzzle made from used goods can stimulate all aspects of child development in the new normal era, in cognitive development, religious morals, language, social emotional, fine motoric skills, art and children's creativity.

Keywords: Children development stimulation, used goods, watch puzzle, new normal era.

Abstrak: Tujuan penelitian ini adalah untuk mendeskripsikan penerapan permainan puzzle jam yang dibuat dari barang bekas dapat menstimulasi perkembangan anak di era new normal. Penelitian ini berjenis kualitatif deskriptif dengan teknik pengumpulan data wawancara, observasi, dan 
dokumentasi. Peneliti melakukan observasi partisipan pada warga yang tinggal di Perumahan Graha Kencana Blok RR no. 12 dengan subjek penelitian ada 3 anak yang berusia 5-6 Tahun dan 2 orang tua yang mendampingi anak bermain. Penelitian ini dilakukan pada masa pandemi covid19, khususnya di era new normal. Hasil penelitian menunjukkan bahwa alat permainan edukatif puzzle jam yang terbuat dari barang bekas dapat menstimulasi seluruh aspek perkembangan anak di era new normal, baik perkembangan kognitif, moral agama, bahasa, sosial emosional, motorik halus, seni dan kreativitas anak.

Kata kunci: Stimulasi perkembangan anak, barang bekas, puzzle jam, era new normal.

\section{A. Pendahuluan}

Covid-19 (corona virus disease-19) telah menjadi topik panas yang sangat mencemaskan masyarakat di seluruh dunia, terutama sejak virus corona diumumkan sebagai pandemik global. Covid-19 merupakan penyakit infeksi yang diakibatkan oleh virus corona (Rohita, 2020, p. 316). Data sebaran terakhir pertanggal 24 April 2021 menunjukkan kasus covid-19 terkonfirmasi di seluruh dunia (223 Negara) sebanyak 144.358.956 dan meninggal sebanyak 3.066.113. Sedangkan penyebaran kasus covid-19 di Indonesia positif sebanyak 1.636.792, sembuh 1.492.322, dan warga yang meninggal sebanyak 44.500 (Covid-19, 2021).

Di banyak negara termasuk Negara Indonesia, jumlah kasus covid-19 terus meningkat dan berada pada situasi yang mengkhawatirkan. Hal ini menjadikan kenyataan yang tidak diinginkan oleh banyak orang (United Nations, 2020). Demi memutuskan rantai penyebaran covid-19 di Indonesia, Pemerintah telah berupaya dalam membuat kebijakan PSBB (pembatasan sosial berskala besar). Penerapan kebijakan PSBB ini berdampak luas pada seluruh aspek kehidupan masyarakat, baik dari segi kesehatan, ekonomi, politik, sosial budaya, hukum, dan juga pendidikan, di mulai dari perguruan tinggi hingga jenjang pendidikan terendah, yaitu pendidikan anak usia dini (Agustin et al., 2020, p. 334). Hal ini mengakibatkan Menteri Pendidikan dan Kebudayaan (Mendikbud), Nadiem Anwar 
Makarim terpaksa mengeluarkan kebijakan pembelajaran jarak jauh atau pembelajaran online dengan menerbitkan surat edaran nomor 4 tahun 2020 tentang pelaksanaan pendidikan dalam masa darurat corona virus disease (covid-19). Pembelajaran jarak jauh atau dalam jaringan (daring) perlu difokuskan untuk meningkatkan pemahaman peserta didik mengenai wabah covid-19. Pembelajaran daring ini sangat penting dilakukan untuk menjaga keamanan peserta didik dan juga guru di seluruh Indonesia (RI, 2020).

Pembelajaran daring pada masa pandemi di sekolah menjadi suatu hal yang baru dan menantang bagi stakeholder pendidikan, termasuk peserta didik dan guru. Hal ini membuat dunia pendidikan harus memiliki kesiapan dalam menjalankan proses pembelajaran selama masa pandemi (Handayani et al., 2020, p. 3). Pada masa pandemi ini mengharuskan orang-orang untuk terus-menerus berada di rumah, sehingga menyebabkan kebosanan dan stress pada orang tua, terutama anak-anak. Oleh karena itu, orang tua harus terus berusaha untuk memahami cara membuat anak agar tidak merasa jenuh dan bosan selama berada di rumah (Mastoah \& MS, 2020, p. 121). Satu hal penting yang harus diperhatikan orang tua adalah memenuhi kebutuhan psikososial anak selama masa pandemi. Hal ini mampu mengurangi dampak psikososial seperti rasa stress yang mungkin terjadi yang dapat mempengaruhi mental, perilaku, dan aktivititas anak. Eka Hidayati selaku spesialis perkembangan anak mengatakan bahwa pandemi ini dapat membuat anak-anak merasa bingung, khususnya bagi anak berusia di atas dua tahun (Rohayani, 2020, p. 30).

Pada dasarnya orang tua berkewajiban dan bertanggungjawab dalam tugas mendidik anak dengan memberikan berbagai hal menyangkut kepentingan anakanaknya, seperti mengembangkan kemampuan, pengetahuan, keterampilan, dan menjaga kesehatan anak (Rochanah, 2017, p. 189). Meskipun demikian, apabila orang tua sudah mulai bekerja di era new normal, maka pengasuhan dapat dilakukan oleh orang dewasa lainnya yang dekat dengan Sang Anak. New normal adalah suatu kondisi di era pandemi yang memungkinkan orang-orang menjalani kehidupan seperti biasa dengan tetap memperhatikan protokol kesehatan karena obat dan vaksin corona belum ditemukan (Mega et al., 2020, p. 76). Prinsip pengasuhan anak pada dasarnya tidak terpaku pada 
siapa pengasuhnya, akan tetapi lebih terfokus pada aktivitas yang diberikan oleh orang dewasa dari pendidikan yang dapat menstimulasi perkembangan anak. Faktor terpenting dalam perkembangan anak yang sehat adalah memiliki setidaknya satu hubungan yang kuat (keterikatan) dengan orang dewasa yang peduli dan menghargai kesejahteraan anak. Kurangnya pengasuh yang konsisten dapat menimbulkan risiko tambahan bagi anak-anak (Evans, 2007, p. 4). Berdasarkan data WHO pada tahun 2016 menunjukkan bahwa sekitar 250 juta anak (43\%) tidak mampu mencapai perkembangan secara optimal di seluruh dunia. Di benua Afrika, angka presentase menunjukkan lebih dari 40\% anak berusia 3-5 tahun mengalami kegagalan dalam mengembangkan kemampuan kognitif dan emosionalnya. Hal ini dikarenakan kesalahan pengasuh yang kurang memberi dukungan dalam pembelajaran anak usia dini, seperti informasi dan sarana. Faktor-faktor yang mempengaruhi keberhasilan pola asuh, antara lain sosial budaya, ekonomi, pendidikan, lingkungan, dan dukungan pengasuh (Sary, 2020, p. 328). Sedangkan di Indonesia, prevalensi penyimpangan perkembangan pada anak usia dini di bawah 5 tahun sebesar 7.512 per 100.000 populasi anak (7,51\%). Diperkirakan sekitar 5 hingga 10\% anak mengalami keterlambatan perkembangan (Inggriani et al., 2019, p. 116).

Oleh karena itu, pentingnya ada dukungan dari orang tua atau pengasuh agar perkembangan anak dapat dioptimalkan dan penyimpangan perkembangan dapat diminimalisir. Dukungan orang dewasa ini memungkinkan anak-anak kecil untuk mendekati kesempatan belajar dengan lebih positif dan percaya diri (Institute of Medicine and National Research Council of the National Academies, 2015, p. 100). Interaksi pendidikan dan stimulasi pola asuh yang efektif dapat dijalankan dengan aktivitas bermain. Tentunya hal ini dapat menstimulasi aspek-aspek perkembangan anak, seperti agama moral, bahasa, fisik motorik, sosial emosional, kognitif, seni dan kreativitas. Pada era pandemi dan new normal ini, banyak orang tua yang membebaskan anak usia dini dalam mengakses gadget. Hasil penelitian Yuli dan Ria mengungkapkan bahwa dalam proses pembelajaran yang menggunakan gadget mampu menumbuhkan minat belajar anak dan sekaligus sebagai alat untuk melengkapi sarana proses pembelajarannya (Hijriyani \& Astuti, 2017, pp. 15-16). Akan tetapi, penggunaan gadget ini 
apabila tanpa pengawasan akan menyebabkan kecanduan dan ketergantungan. Untuk meminimalisir kecanduan gadget pada anak, maka orang tua atau pengasuh perlu kreatif ketika memberikan permainan yang dapat menstimulasi perkembangan anak secara optimal.

Salah satu strategi yang dapat dilaksanakan orang tua atau pengasuh untuk menstimulasi perkembangan anak adalah dengan mengajak anak membuat alat permainan edukatif (APE) yang dapat dimanfaatkan atau dibuat dari barang bekas yang mudah di dapat dari lingkungan sekitarnya, seperti kotak kardus, kertas, plastik yang tidak digunakan lagi. Menurut Novan, ada empat tahap yang dapat dilakukan ketika membuat APE, yaitu menentukan alat dan bahan; proses pembuatan (langkah-langkah dalam membuat APE); cara menggunakan APE; dan evaluasi penggunaan APE (Wigati \& Wiyani, 2020, p. 43). Hal ini juga termasuk dalam membuat APE dari barangbarang bekas. Produk yang dihasilkan dari barang bekas dapat menjadi sesuatu yang bernilai apabila dapat dimanfaatkan dengan baik. Tentunya hal ini dapat membuat anak lebih kreatif dan bisa menjadi altrenatif dalam menangkap peluang serta kepekaan kepada lingkungan yang ada di sekitarnya. (Anggraini, 2018, p. 29). Hasil penelitian menunjukkan bahwa kepedulian pada lingkungan hidup harus sudah ditanamkan pada anak sejak usia dini dengan cara memanfaatkan barang bekas yang dapat di daur ulang (Harahap \& Widyaningsih, 2019, p. 480). Hal ini dapat membantu mengatasi permasalahan limbah-limbah atau sampah-sampah yang sering kali mencemar lingkungan kita.

Oleh karena itu, untuk mengatasi kejenuhan dan kecanduan gadget pada anak usia dini, maka pengasuh harus memberikan kegiatan atau permainan kreatif untuk menarik perhatian Sang Anak. Salah satu permainan yang memanfaatkan barang bekas adalah Puzzle Jam. Puzzle ini dapat dibuat dari bahan plastik, kertas, spon, ataupun kayu tebal. Puzzle jam adalah suatu permainan berbentuk puzzle dengan menggunakan media papan triplek berukuran $30 \times 20 \mathrm{~cm}$ yang di dalamnya terdapat bentuk jam beserta isi angka dan jarum jam. Potongan-potongan puzzle yang yang sudah dilabeli angka jam dapat dibongkar pasang, lalu anak-anak dapat diminta untuk menata ulang angka-angka tersebut searah jarum jam. Puzzle jam ini memiliki cara kerja yaitu dengan cara meminta anak untuk mempreteli 
kepingan puzzle, lalu anak menata ulang angka-angka tersebut dicocokkan searah jarum jam (Tanjung, Nurmiati; Efastri, 2019, p. 18). Puzzle jam ini memiliki banyak manfaat dalam menstimulasi perkembangan anak, terutama perkembangan kognitif anak. Muloke dalam penelitiannya mengungkapkan bahwa APE seperti puzzle memiliki pengaruh dalam mengembangkan kemampuan kognitif anak yang berusia 5 hingga 6 tahun (Muloke et al., 2017). Selain itu, Ismawati dalam penelitiannya mengungkapkan bahwa permainan edukatif puzzle jam dapat mengajarkan anak mengenal bilangan (Ismawati, 2016, p. 200). Permainan puzzle dapat menstimulasi perkembangan anak juga diperkuat dengan penelitian yang telah dilakukan oleh Tunggul dan Hesti yang mengungkapkan bahwa pemberian stimulasi puzzle memiliki pengaruh yang positif terhadap perkembangan sosial dan kemandirian anak (Setyaningsih, 2018, p. 62). Berdasarkan beberapa pemaparan yang telah dijabarkan di atas, maka penelitian ini bertujuan untuk mendeskripsikan permainan puzzle jam yang terbuat dari bahan bekas dapat menstimulasi perkembangan anak di era new normal.

\section{B. Metode}

Penelitian ini merupakan penelitian berjenis kualitatif yang bersifat deskriptif. Penelitian ini bersifat deskriptikf karena dalam penelitian ini bertujuan untuk mendeskripsikan situasi atau fenomena apa adanya (Sukmadinata, 2009, p. 18). Penelitian ini dilakukan pada bulan Desember 2020 di Kota Pamekasan, Pulau Madura, Provinsi Jawa Timur. Penelitian ini menggunakan teknik pengumpulan data yaitu wawancara, observasi, dan dokumentasi. Peneliti melakukan observasi partisipan pada warga yang tinggal di Perumahan Graha Kencana Blok RR no. 12 dengan subjek penelitian anak yang berusia 5-6 tahun berjumah tiga orang. Selain itu, peneliti melakukan wawancara dengan tidak terstruktur untuk melihat dan mendengarkan pengalaman anak-anak yang bermain puzzle jam. Pada sisi lain, peneliti juga mewawancarai orang tua mereka yang mendampingi anak-anaknya bermain puzzle jam. Tentunya peneliti juga melakukan dokumentasi selama aktivitas bermain ini berlangsung. Setelah itu, peneliti menggunakan model Miles dan Huberman untuk menganalisis data yang berupa langkah-langkah, seperti sebagai betikut: data 
collection; data reduction; data display; dan conclusion (Sugiyono, 2016, p. 338). Langkah analisis data ini dapat ditunjukkan pada gambar 1:

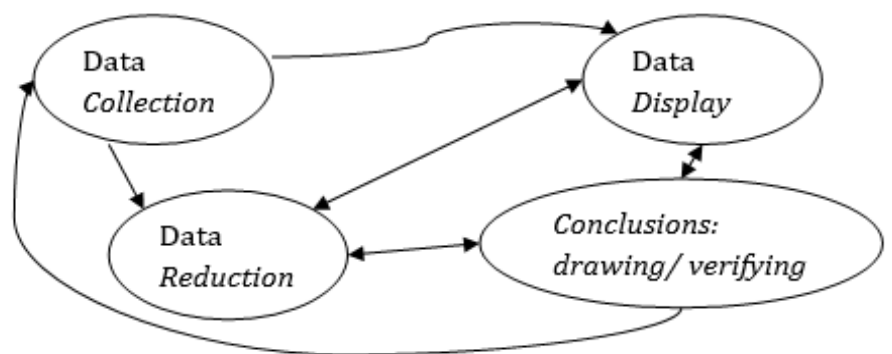

Gambar 1. Komponen Analisis Data Miles dan Huberman

\section{Hasil Penelitian}

Alat permainan edukatif berupa puzzle jam ini dapat dibuat oleh orang tua dan anak dengan memanfaatkan barang bekas yang mudah ditemui di lingkungan sekitar rumahnya. Orang tua yang sudah bekerja di era new normal bisa membuat media permainan ini pada saat sudah pulang kerja atau di hari libur. Permainan edukatif puzzle jam ini dapat dilakukan sendirian atau bersama dengan teman, atau didampingi oleh orang tua maupun pengasuh lainnya.

Berikut cara membuat Alat Permainan Edukatif (APE) Puzzle Jam.

Alat dan bahan:

1. Kardus bekas

2. Kotak susu bekas

3. Kertas kado

4. Karton

5. Kertas asturo

6. Kertas origami

7. Gambar buah-buahan dan hewan

8. Gunting

9. Lem

10. Piring dan tutup botol

11. Spidol

Cara Membuat: 
1. Gunting kerangka berbentuk persegi panjang untuk puzzle dari kardus sesuai ukuran yang dinginkan.

2. Tempelkan kertas kado di kerangka kardus berbentuk persegi panjang tersebut.

3. Bentuk pola jam menggunakan piring dan pola puzzle.

4. Tempelkan kardus dan karton pada pola jam dan pola puzzle.

5. Gunting kertas origami berbentuk bulat dengan menggunakan tutup botol.

6. Tempelkan angka jam 1-12 pada kertas origami, lalu tempelkan angka tersebut di pola jam.

7. Tempelkan gambar binatang dan buahbuahan di pola puzzle sesuai dengan angka di pola jam.

Pemainan puzzle jam ini banyak memberikan pengetahuan kepada anak. Cara memainkan puzzle jam ini, yaitu:

a. Orangtua atau pengasuh menjelaskan terlebih dahulu cara bermain puzzle jam kepada anak dengan cara mencocokan dan memasangkan puzzle sesuai dengan pola yang sudah terbentuk. Misalnya seperti gambar binatang bebek pada pola puzzle berjumlah 7 ekor, maka puzzle dipasangkan pada jam yang menunjukkan angka 7 .

b. Anak-anak diminta untuk mencocokkan dan memasang puzzle secara bergantian dan secara bersama-sama.

c. Orangtua atau pengasuh dapat bertanya kepada anak tentang nama-nama binatang, buah-buahan, angka, dan warna yang terdapat dalam puzzle jam.

Berikut merupakan penjelasan dari permainan puzzle jam yang memanfaatkan barang bekas yang dapat menstimulasi perkembangan anak didik secara optimal.

Tujuan Pembelajaran

(Indikator dan Aspek yang

Dicapai)

Tema : Alam Sekitar 
Sub tema : Macam-macam Binatang dan Buah-Buahan

Media : Puzzle Jam

Tujuan :
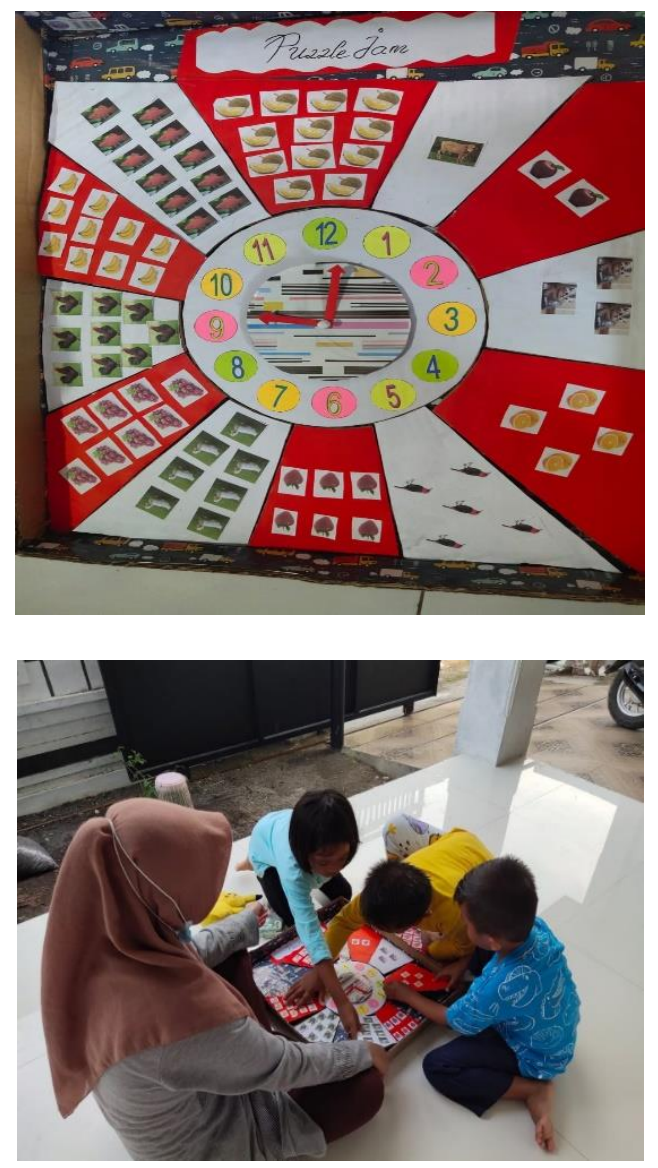

Gambar 2. Puzzle Jam dengan Bahan Barang Bekas (atas) | Gambar 3. Anak Bermain Puzzle Jam (bawah)

1. Anak mampu mencocokkan dan memasangkan potongan puzzle sesuai pola yang sudah terbentuk (Kognitif)

2. Anak mampu mengetahui bahwa binatang dan buah-buahan merupakan ciptaan Allah dan membentuk karakter mandiri, cinta tanah air dan nasionalisme (Moral Agama) 
3. Menyebutkan nama-nama binatang, buah-buahan, warna, dan lambang bilangan pada puzzle jam (Bahasa)

4. Anak mampu mencocokkan dan memasangkan potongan puzzle secara bergilir dan bersama teman-teman (Sosial dan Emosional)

5. Anak mampu mengkoordinasikan fungsi mata dan tangan ketika menyusun puzzle (Motorik Halus)

6. Anak mampu menentukan warna-warna yang beragam di puzzle (Seni dan Kreativitas)

Beberapa aspek perkembangan yang dicapai:

a. Aspek Perkembangan Kognitif

Upaya yang dilakukan orang tua atau pengasuh agar dapat menstimulasi aspek perkembangan kognitif anak melalui media puzzle jam yaitu meminta anak mencocokkan dan memasangkan puzzle secara tepat sesuai antara gambar jam yang terdapat lambang bilangan 1-12 dengan pola gambar binatang atau buah-buahan. Misalnya pada gambar binatang kucing berjumlah 3 ekor, maka anak dapat mencocokkan dan memasangkan puzzle pada jam angka 3 .

b. Apek Perkembangan Moral Agama

Upaya yang dilakukan orang tua atau pengasuh agar dapat menstimulasi aspek perkembangan moral agama anak melalui media puzzle jam yaitu dengan bertanya kepada anak bahwa siapa yang menciptakan binatang dan buah-buahan, mengatakan kepada anak agar tidak berlaku kasar terhadap binatang ciptaan Allah, dan tidak boleh membuang-buang makanan (buah), serta membentuk karakter cinta tanah air dan nasionalisme pada anak.

c. Aspek Perkembangan Bahasa

Upaya yang dilakukan orang tua atau pengasuh agar dapat menstimulasi aspek perkembangan bahasa anak melalui media puzzle jam yaitu meminta anak untuk menyebutkan nama-nama binatang dan buah-buahan; menyebutkan angka; dan menyebutkan warna dalam bahasa Indonesia maupun bahasa Inggris

d. Aspek Perkembangan Sosial Emosional

Upaya yang dilakukan orang tua atau pengasuh agar dapat menstimulasi aspek perkembangan sosial emosional anak melalui media puzzle jam yaitu meminta anak bermain puzzle 
jam secara mandiri dan bergilir, serta bermain dengan temanteman secara bersamaan, dan melihat segi emosi anak apakah bermain dengan sabar dan tenang atau malah sebaliknya.

e. Aspek Perkembangan Motorik Halus

Upaya yang dilakukan orang tua atau pengasuh agar dapat menstimulasi aspek perkembangan motorik halus anak melalui media puzzle jam yaitu meminta anak agar dapat menggerakkan tangan dan mata dalam menyusun puzzle jam. Dalam menyusun puzzle jam membutuhkan koordinasi antara mata dan tangan agar puzzle dapat terbentuk secara benar.

f. Aspek Perkembangan Seni dan Kreativitas

Upaya yang dilakukan orang tua atau pengasuh agar dapat menstimulasi aspek perkembangan seni dan kreativitas anak melalui media puzzle jam yaitu meminta anak melakukan kegiatan eksplorasi bermain secara aktif dan menentukan beragam warna yang ada di puzzle jam. Dalam pembuatan puzzle jam menggunakan warna-warna yang menarik agar anak tidak bosan.

Dari penjabaran pemaparan di atas, maka dapat diketahui bahwa media permainan puzzle jam yang terbuat dari barang bekas terbukti mampu menstimulasi semua aspek perkembangan anak sesuai tujuan pembelajaran yang ingin dicapai. Meskipun pada masa pandemi covid-19 dan era new normal anak hanya berada di rumah, permainan ini dapat dilakukan untuk menghilangkan rasa bosan pada anak, sekaligus mampu memberikan stimulasi terhadap semua aspek perkembangan anak, yaitu perkembangan kognitif, moral agama, bahasa, sosial emosional, motorik halus, seni, dan kreativitas.

\section{Pembahasan}

Permainan yang baik adalah permainan yang banyak memiliki manfaat dalam menstimulasi perkembangan anak secara keseluruhan, baik itu perkembangan kognitif, moral agama, bahasa, sosial emosional, fisik motorik, seni dan kreativitas (Ismawati, 2016). Dalam membuat alat permainan edukatif, kita dapat memanfaatkan barang bekas sehingga menjadi barang yang bernilai guna. Barang bekas yang dimanfaatkan sebagai media pembelajaran bukan sesuatu yang baru. Sampah yang bertumpuk dan dibuang dengan 
sembarangan akan menyebabkan banjir atau pencemaran lingkungan lainnya. Oleh karena itu harus bisa mendaur ulang sampah agar bernilai guna, termasuk untuk membuat alat permainan edukatif pada anak. Hasil kegiatan pengabdian masyarakat yang telah dilaksanakan oleh Winata dan kawankawan mengungkapkan bahwa pemanfaatan barang bekas menjadi APE merupakan peluang yang besar agar sampah bisa dimanfaatkan kembali menjadi media yang bernilai guna (Winata et al., 2019, p. 3). Pembuatan APE saat di rumah dapat dilakukan oleh orang tua dengan memanfaatkan barang bekas, sawah, kebun, akuarium, pabrik atau bahkan daun-daun atau bonggol jagung hasil pertanian yang dapat dijadikan alat permainan (Hasiana, 2020, p. 32). Kegiatan ini dapat dilakukan bersama anak-anak sambil bermain dengan cara yang menyenangkan (Bustan et al., 2017, p. 282). Ada beberapa hal yang perlu menjadi perhatian dalam membuat media pembelajaran sebagaimana yang diungkapkan oleh Haryono, terdapat hal-hal yang perlu diperhatikan ketika membuat media pembelajaran, seperti sebagai berikut: (1) memiliki tujuan atau capaian pembelajaran, (2) menjelaskan tentang isi materi pembelajaran, (3) praktis, (4) tepat sasaran dalam mengoptimalisasikan perkembangan anak, dan (5) memiliki mutu yang baik (Haryono, Sarah Emmanuel; Anggraini, 2017, p. 471).

Salah satu media pembelajaran yang bisa dibuat oleh orang tua dan anak saat pembelajaran di rumah adalah puzzle jam. Puzzle merupakan media visual bersifat dua dimensi yang memiliki kemampuan untuk menyampaikan semua informasi tentang segala sesuatu sebagai pindahan dari bentuk aslinya. Cara memainkan media ini adalah dengan memasangkan gambar atau benda dari sebuah puzzle yang telah dipecah menjadi beberapa bagian dengan melibatkan koordinasi fungsi mata dan tangan saat menyusun puzzle sehingga terbentuklah puzzle yang utuh. Puzzle dapat dibuat dari bahan plastik, kertas, spon, ataupun kayu tebal. Puzzle jam adalah suatu permainan berbentuk puzzle dengan menggunakan media papan triplek berukuran $30 \times 20 \mathrm{~cm}$ yang di dalamnya terdapat bentuk jam beserta isi angka dan jarum jam. Potongan-potongan puzzle yang yang sudah dilabeli angka jam dapat dibongkar pasang, lalu anak-anak dapat diminta untuk menata ulang angka-angka tersebut searah jarum jam. Puzzle jam ini memiliki cara kerja 
yaitu dengan cara meminta anak untuk mempreteli kepingan puzzle, lalu anak menata ulang angka-angka tersebut dicocokkan searah jarum jam (Tanjung, Nurmiati; Efastri, 2019, p. 18).

Pada masa new normal, orang tua atau pengasuh dapat mengajak anak untuk bermain sambil belajar ketika berada di rumah, salah satunya yaitu mengajak anak bermain puzzle jam. Berdasarkan penelitian yang telah dilakukan, permainan puzzle jam ini terbukti mampu menstimulasi semua aspek perkembangan anak di masa new normal. Tidak hanya guru, orang tua juga berkewajiban untuk mampu membuat anak belajar sambil bermain sesuai tujuan pembelajaran agar semua aspek perkembangan anak dapat distimulasi meskipun pembelajaran hanya dilakukan di lingkungan sekitar rumah. Meskipun demikian, orang tua tetap harus senantiasa memberikan perlindungan kepada anak ketika bermain puzzle jam agar anak tetap dapat mengeksplor bakat dan kreativitasnya tanpa khawatir terpapar virus dengan menjalankan protokoler kesehatan.

Dalam penelitian ini, permainan puzzle jam yang terbuat dari barang bekas memiliki manfaat dalam menstimulasi semua aspek perkembangan anak, seperti perkembangan kognitif, moral agama, bahasa, motorik halus, sosial emosional, seni dan kreativitas. Hasil penelitian yang telah dilakukan sejalan dengan penelitian Muloke yang mengungkapkan bahwa permainan edukatif puzzle berpengaruh dalam mengembangkan kemampuan kognitif anak yang berusia 5 hingga 6 tahun (Muloke et al., 2017). Hal senada juga disampaikan oleh Ismawati dalam penelitiannya yang mengungkapkan bahwa permainan edukatif puzzle jam dapat mengajarkan anak mengenal bilangan (Ismawati, 2016, p. 200). Kemampuan mengenal bilangan berhubungan erat dengan perkembangan kognitif anak. Selain itu, hal ini juga diperkuat oleh penelitian yang dilakukan oleh Tunggul dan Hesti yang menyatakan bahwa pemberian stimulasi puzzle berpengaruh terhadap perkembangan sosial dan kemandirian anak (Setyaningsih, 2018, p. 62) . Ketiga penelitian ini dilakukan pada saat masa sebelum adanya pandemi covid-19. Berbeda dengan penelitian yang dilakukan pada saat masa pandemi covid-19.

Pandemi covid-19 mampu merubah tatanan hidup masyarakat di seluruh dunia, sehingga masyarakat diimbau oleh 
Pemerintah bahkan dipaksa untuk tinggal di rumah guna mencegah penularan wabah virus corona. Bahkan sekolah, bekerja, dan aktivitas ibadah pun dianjurkan untuk dilaksanakan di rumah saja. Akan tetapi seiiring berjalannya waktu, tinggal di rumah saja tidak mampu menjaga keseimbangan perekonomian negara sehingga memaksa Pemerintah mengeluarkan kebijakan baru yaitu pola hidup baru atau new normal. New normal adalah suatu perubahan tatanan perilaku dalam menjalankan aktivitas normal namun ditambah dengan menerapkan protokoler kesehatan guna mencegah penularan atau penyebaran covid-19 (Bramasta, 2020). Meskipun pada era new normal, pembelajaran dilakukan secara jarak jauh dari rumah, bukan menjadi penghalang bagi orang tua atau mengasuh dalam memberikan pembelajaran yang bermakna kepada anak-anaknya. Dalam kondisi seperti ini memaksa orang tua untuk lebih kreatif mengembangkan proses pembelajaran agar tujuan pembelajaran bagi anak usia dini dapat tercapai, yaitu menstimulasi seluruh aspek perkembangan anak. Dalam mengembangkan bahan pelajaran seperti APE untuk anak tidak harus selalu membeli barang baru, tetapi bisa memanfaatkan barang bekas. Mengajak anak untuk bermain APE seperti puzzle jam yang terbuat dari barang bekas di era new normal dapat dilakukan ketika anak dan orang tua sedang berada di rumah saja atau anak bermain bersama teman sebaya di lingkungan sekitar dengan selalu menerapkan protokol kesehatan. Berdasarkan pemaparan di atas, maka dapat diketahui bahwa alat permainan edukatif puzzle jam yang terbuat dari barang bekas mampu menstimulasi seluruh aspek perkembangan anak.

\section{E. Simpulan}

Media permainan edukatif puzzle jam yang terbuat dari barang bekas terbukti mampu menstimulasi semua aspek perkembangan anak yang berusia 5 sampai 6 tahun di era new normal, baik dari perkembanagn kognitif, moral agama, bahasa, sosial emosional, motorik halus, seni dan kreativitas. Permainan ini mudah dimainkan oleh anak, baik dengan pendampingan orang tua maupun dilakukan secara mandiri bersama terman sebaya dengan selalu memperhatikan protokoler kesehatan. 


\section{Referensi}

Agustin, M., Puspita, R. D., Nurinten, D., \& Nafiqoh, H. (2020).

Tipikal Kendala Guru PAUD dalam Mengajar pada Masa

Pandemi Covid 19 dan Implikasinya. Jurnal Obsesi : Jurnal Pendidikan Anak Usia Dini, 5(1), 334.

https://doi.org/10.31004/obsesi.v5i1.598

Anggraini, D. (2018). Pengembangan Alat Permainan Edukatif Dengan Barang Bekas Untuk Mengembangkan Bahasa Anak Usia Dini Di Ra Al-Hidayah Kecamatan Kasui Kabupaten Waykanan.

Bramasta, D. B. (2020). Mengenal Apa Itu New Normal di Tengah Pandemi Corona. Kompas.Com. https://www.kompas.com/tren/read/2020/05/20/06310 0865/mengenal-apa-itu-new-normal-di-tengah-pandemicorona-?page $=$ all

Bustan, R., Nurfadilah, N., \& Fitria, N. (2017). Pelatihan Optimalisai Tumbuh Kembang Anak pada Orangtua Anak Usia Dini. Jurnal Al-Azhar Indonesia Seri Humaniora, 3(3), 274. https://doi.org/10.36722/sh.v3i3.214

Covid-19, S. (2021). Data Sebaran. covid19.go.id

Evans, J. L. (2007). Parenting programmes : an important ECD intervention strategy.

Handayani, J. A., Al-Bahij, A., Bahar, H., \& ... (2020). Analisis Kesiapan Pembelajaran Daring Peserta Didik Kelas I Sekolah Dasar Negeri Ciputat 04 di Masa Pandemi Covid-19. ... Nasional Penelitian LPPM ..., 1-5.

https://jurnal.umj.ac.id/index.php/semnaslit/article/view/ 7868

Harahap, D. H., \& Widyaningsih, S. S. (2019). Kreativitas Pada Kegiatan Pemanfaatan Kembali Sampah (Reuse ). 2010, 477-483.

Haryono, Sarah Emmanuel; Anggraini, H. M. S. (2017).

Pengembangan Media Pembelajaran untuk Anak Usia Dini dari Bahan Bekas. Seminar Nasional Hasil Penelitian Universitas Kanjuruhan Malang, 5(1), 470-472.

Hasiana, I. A. I. A. dan A. F. (2020). Optimalisasi Lingkungan Sekitar Sebagai Sumber Belajar Anak Usia Dini Di Desa Tawar Kecamatan Gondang Kabupaten Mojokerto. Jurnal Abadimas Adi Buana, 4(1), 29-34.

Hijriyani, Y. S., \& Astuti, R. (2017). Penggunaan Gadget oleh Anak Usia Dini pada Era Revolusi Industri 4.0. ThufuLA: 
Jurnal Inovasi Pendidikan Guru Raudhatul Athfal, 8(1), 1528.

Inggriani, D. M., Rinjani, M., \& Susanti, R. (2019). Deteksi Dini

Tumbuh Kembang Anak Usia 0-6 Tahun Berbasis Aplikasi Android. Wellness And Healthy Magazine, 1(1), 115-124. Institute of Medicine and National Research Council of the National Academies. (2015). Child development and early learning. In Transforming the Workforce for Children Birth Through Age 8: A Unifying Foundation.

Ismawati, P. (2016). Penggunaan alat permainan edukatif "puzzle jam" terhadap kemampuan kognitif "mengenal lambang bilangan." Jurnal Program Studi PGRA, 2(1), 200207.

Mastoah, I., \& MS, Z. (2020). Kendala Orang Tua Dalam Mendampingi Anak Belajar Pada Masa Covid 19 Di Kota Serang. As-Sibyan: Jurnal Pendidikan Anak Usia Dini, 5(2), 121-128.

http://jurnal.uinbanten.ac.id/index.php/assibyan/article/vi ew/3663

Mega, N., Saputra, A., \& Muharammah, N. W. (2020). Peran

Layanan Bimbingan dan Konseling Sebagai Internalisasi Kemampuan Adaptasi Peserta Didik pada Era New Normal. Prosiding Seminar Bimbingan Dan Konseling, 0(0), 75-79.

Muloke, I., Ismanto, A., \& Bataha, Y. (2017). Pengaruh Alat

Permainan Edukatif (Puzzle) Terhadap Perkembangan Kognitif Anak Usia 5-6 Tahun Di Desa Linawan Kecamatan Pinolosian Kabupaten Bolaang Mongondow Selatan. Jurnal Keperawatan UNSRAT, 5(1), 111977.

RI, K. (2020). Mendikbud Terbitkan SE tentang Pelaksanaan Pendidikan dalam Masa Darurat Covid-19.

https://www.kemdikbud.go.id/

Rochanah, R. (2017). Peranan Keluarga Sekolah Dan

Masyarakat Dalam Menunjang Pembelajaran Yang Efektif. ELEMENTARY: Islamic Teacher Journal, 4(1).

https://doi.org/10.21043/elementary.v4i1.1981 Rohayani, F. (2020). Menjawab Problematika Yang Dihadapi Anak Usia Dini di Masa. Qawwam: Journal For Gender Mainstreaming, 14(1), 29-50. https://doi.org/10.20414/Qawwam.v14i1.2310 Rohita, R. (2020). Pengenalan Covid-19 pada Anak Usia Prasekolah: Analisis pada Pelaksanaan Peran Orangtua di 
Rumah. Jurnal Obsesi : Jurnal Pendidikan Anak Usia Dini, 5(1), 315. https://doi.org/10.31004/obsesi.v5i1.528

Sary, Y. N. E. (2020). Cara Asuh Nenek pada Anak Usia Dini di Masa Pandemi Covid-19. Jurnal Obsesi : Jurnal Pendidikan Anak Usia Dini, 5(1), 327. https://doi.org/10.31004/obsesi.v5i1.585

Setyaningsih, T. S. A. dan H. W. (2018). Stimulasi Permainan Puzzle Berpengaruh Terhadap Perkembangan Sosial dan Kemandirian Anak Usia Prasekolah. Jurnal Keperawatan Silampari (JKS), 1(2).

Sugiyono. (2016). Metode Penelitian Pendidikan: Pendekatan Kuantitatif, Kualitatif, dan R \& D. Alfabeta.

Sukmadinata, N. S. (2009). Metodologi Penelitian Pendidikan. PT Remaja Rosdakarya.

Tanjung, Nurmiati; Efastri, S. M. (2019). Upaya Meningkatkan Kemampuan Mengenal Lambang Bilangan melalui Bermain Puzzle Jam Anak Usia 4-5 tahun Di PAUD Generasi Bangsa Pekanbaru. PAUD Lectura: Jurnal Pendidikan Anak Usia Dini, 2(2), 13-24. https://doi.org/https://doi.org/10.31849/paudlectura.v2i02.2496

United Nations. (2020). Impact of the COVID-19 pandemic on trade and development.

Wigati, M., \& Wiyani, N. A. (2020). Kreativitas Guru Dalam Membuat Alat Permainan Edukatif Dari Barang Bekas. AsSibyan: Jurnal Pendidikan Anak Usia Dini, 5(1), 43. https://doi.org/10.32678/as-sibyan.v5i1.2700

Winata, W., Fitriawaty, D., Hasanah, W., \& Octavianti, D. (2019). Alat Permainan Edukatif dari Barang Bekas. Prosiding Seminar Nasional Pengabdian Masyarakat LPPM UMJ, September, 1-5. 
34 | Yuniatari \& Suyadi 